\title{
Syntheses and Structures of Tungsten o-(Diphenylphosphino)benzaldehyde Complexes Bearing $\pi$-Bonded Aldehyde Groups
}

\author{
Wen-Yann Yeh* and Cha-Shie Lin \\ Department of Chemistry, National Sun Yat-Sen University, Kaohsiung, Taiwan 804 \\ Shie-Ming Peng and Gene-Hsiang Lee \\ Department of Chemistry, National Taiwan University, Taipei, Taiwan 106
}

Recei ved November 18, 2003

\begin{abstract}
Summary: Reaction of the bidentate ligand $\mathrm{Ph}_{2} \mathrm{P}$ (o$\left.\mathrm{C}_{6} \mathrm{H}_{4}\right) \mathrm{C}(=\mathrm{O}) \mathrm{H}$ (abbreviated as $\mathrm{PCHO}$ ) with $\mathrm{W}(\mathrm{CO})_{3}\left(\eta^{3}-\right.$ $\left.\left(\mathrm{MeNCH}_{2}\right)_{3}\right)$ at room temperature affords $\mathrm{W}(\mathrm{CO})_{3}\left(\eta^{1-}\right.$ $\mathrm{PCHO})\left(\eta^{3}-\mathrm{PCHO}\right)(\mathbf{1})$, which subsequently loses a carbonyl ligand to giveW(CO) $)_{2}\left(\eta^{3}-\mathrm{PCHO}\right)_{2}$ (2). Further treatment of 2 with $\mathrm{PCHO}$ in refluxing benzene results in carboncarbon coupling of the PCHO ligands to produceW(CO)$\left(\eta^{3}-\mathrm{PCHO}\right)\left(\eta^{3}-(\mathrm{PCHO})_{2}\right)(\mathbf{3})$. The structures of $\mathbf{1}-\mathbf{3}$ have been determined by an X-ray diffraction study. The $\mathrm{PCHO}$ ligands in these compounds act as chelating phosphine-aldehydes with the aldehyde groups coordinating in a $\pi$ fashion.
\end{abstract}

\section{Introduction}

Chelating ligands containing "soft" phosphorus and "hard" nitrogen or oxygen donor atoms can alter the reactivity of metal centers and may be of interest in the design and development of new homogeneous catalytic systems. ${ }^{1}$ The o-(diphenyl phosphino)benzal dehyde molecule $\left(\mathrm{Ph}_{2} \mathrm{P}\left(\mathrm{O}_{-} \mathrm{C}_{6} \mathrm{H}_{4}\right) \mathrm{C}(=\mathrm{O}) \mathrm{H}\right.$; abbreviated as $\left.\mathrm{PCHO}\right)$ is one of the simplest bidentate $\mathrm{P}, \mathrm{O}$-chelating agents. ${ }^{2}$ Four binding modes, depicted in Chart 1 , have been observed for $\mathrm{PCHO}$ in its reactions with transitionmetal complexes. Usually, the phosphine center is coordinated to a metal in advance of the aldehyde group and can serve as a monodentate $\eta^{1-} \mathrm{P}$ donor in $\mathrm{W}(\mathrm{CO})_{5^{-}}$ $(\mathrm{PCHO}),{ }^{3} \mathrm{RhCl}(\mathrm{CO})(\mathrm{PCHO})_{2},{ }^{4}$ and $(\mathrm{Rh}(\mathrm{CO})(\mathrm{PCHO})(\mu-$ $\mathrm{pz}))_{2}\left(\mathrm{pz}=\right.$ pyrazolate) ${ }^{5}$ Subsequent oxidative addition of the aldehyde $\mathrm{C}-\mathrm{H}$ bond on $\mathrm{a} \mathrm{Rh}(\mathrm{I}),{ }^{6} \operatorname{Ir}(\mathrm{I}),{ }^{7} \mathrm{Pt}(0),{ }^{8}$ or $\mathrm{Co}(\mathrm{I})^{9}$ center can generate a phosphine-acyl hydrido complex ( $\mathrm{H}, \eta^{2}-\mathrm{PC}$ mode). On the other hand, the PCHO

(1) (a) Klein, H.-F.; Bickel haupt, A.; J ung, T.; Cordier, G. Organometallics 1994, 13, 2557. (b) Hierso, J .-C.; Amardeil, R.; Bentabet, E.; Broussier, R.; Gautheron, B.; Meunier, P.; Kalck, P. Coord. Chem. Rev. 2003, 236, 143. (c) Braunstein, P.; Durand, J .; Knorr, M.; Strohmann C. Chem. Commun. 2001, 211. (d) Newkome, G. R. Chem. Rev. 1993 93, 2067. (e) Catelano, V. J .; Bennett, B. L.; Muratidis, S.; Noll, B. C. J. Am. Chem. Soc. 2001, 123, 173.

(2) (a) Schiemenz, G. P.; Kaack, H. J ustus Liebigs Ann. Chem. 1973, 1480. (b) Hoots, J . E.; Rauchfuss, T. B.; Wrobleski, D. A. Inorg. Synth. 1982, 21, 175.

(3) Ainscough, E. W.; Brodie, A. M.; Ingham, S. L.; Waters, J . M. Inorg. Chim. Acta 1995, 234, 163.

(4) El Mail, R.; Garralda, M. A.; Hernández, R.; I barlucea, L. J . Organomet. Chem. 2002, 648, 149.

(5) Schumann, H.; Hemling, H.; Ravindar, V.; Badrieh, Y.; Blum, J. J . Organomet. Chem. 1994, 469, 213

(6) (a) Bianchini, C.; Meli, A.; Peruzzini, M.; Ramirez, J . A.; Vacca, A.; Vizza, F.; Zanobini, F. Organometallics 1989, 8, 337. (b) El Mail, R.; Garralda, M. A.; Hernández, R.; I barlucea, L.; Pinilla, E.; Torres, M. R. Organometallics 2000, 19, 5310 .
Chart 1<smiles>[Y]PCC(=O)C=O</smiles>

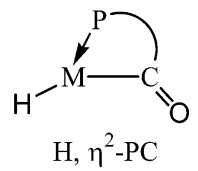

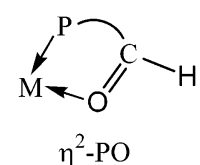

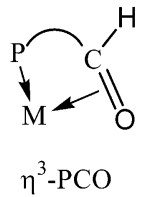<smiles>O=CC=Cc1ccccc1P(c1ccccc1)c1ccccc1</smiles>

ligand can act as a chelating phosphine-aldehyde with the aldehyde moiety bonded to a metal in a $\sigma$ fashion through the oxygen atom ( $\eta^{2}-\mathrm{PO}$ mode), or in a $\pi$ fashion through the carbon-oxygen double bond ( $\eta^{3}$-PCO mode). The $\eta^{2}-\mathrm{PO}$ bonding feature was found in $\mathrm{Re}(\mathrm{CO})_{3} \mathrm{Cl}$ $(\mathrm{PCHO})^{10}$ and $\mathrm{RuCl}_{3}(\mathrm{PCHO})_{2}$, ${ }^{\text {,a }}$ while the $\eta^{3}$-PCO bonding feature has only been suggested for $\mathrm{Cp}{ }^{*} \mathrm{Co}(\mathrm{PCHO})^{11}$ on the basis of NMR spectral data. In this paper we wish to report three structurally characterized tungsten PCHO complexes containing $\pi$-bonded al dehyde groups.

\section{Results and Discussion}

Previously, reactions of the triazacyclohexane complex $\mathrm{W}(\mathrm{CO})_{3}\left(\eta^{3}-\left(\mathrm{MeNCH}_{2}\right)_{3}\right)$ with diphenylacetylene and bis(diphenylphosphino)acetylene have been reported to give the tris(alkyne) complex $\mathrm{W}(\mathrm{CO})(\mathrm{PhC} \equiv \mathrm{CPh})_{3}{ }^{12}$ and the ditungsten helical complex $\mathrm{W}_{2}(\mathrm{CO})_{6}\left(\mu-\mathrm{Ph}_{2} \mathrm{PC} \equiv\right.$ $\left.\mathrm{CPPh})_{2}\right)_{3}{ }^{13}$ respectively. On the other hand, treatment of $\mathrm{W}(\mathrm{CO})_{3}\left(\eta^{3}-\left(\mathrm{MeNCH}_{2}\right)_{3}\right)$ with 3 equiv of $\mathrm{PCHO}$ ligand at room temperature affords the bis-PCHO complex $\mathrm{W}(\mathrm{CO})_{3}\left(\eta^{1}-\mathrm{PCHO}\right)\left(\eta^{3}-\mathrm{PCHO}\right)$ (1) in $54 \%$ yield after crystallization from $\mathrm{n}$-hexane/dichloromethane. During

(7) (a) Rauchfuss, T. B. J . Am. Chem. Soc. 1979, 101, 1045. (b) Landvatter, E. F.; Rauchfuss, T. B. Organometallics 1982, 1, 506. (c) Garralda, M. A.; Hernández, R.; I barlucea, L.; Pinilla, E.; Torres, M. R. Organometallics 2003, 22, 3600.

(8) (a) Koh, J. J .; Lee, W. H.; Williard, P. G.; Risen, W. M. J . Organomet. Chem. 1985, 284, 409. (b) Ghilardi, C. A.; Midollini, S.; Moneti, S.; Orlandini, A. J . Chem. Soc., Dalton Trans. 1988, 1833.

(9) Klein, H. F.; Lemke, U.; Lemke, M.; Brand, A. Organometallics 1998, 17, 4196

(10) Chen, X.; Femia, F. J .; Babich, J . W.; Zubieta, J . Inorg. Chim. Acta 2001, 315, 147.

(11) Lenges, C. P.; Brookhart, M.; White, P. S. Angew. Chem., Int. Ed. 1999, 38, 552.

(13) Yeh, W.-Y.; Peng, S.-M.; Lee, G.-H. J . Organomet. Chem. 2003 671, 145. 
Scheme 1

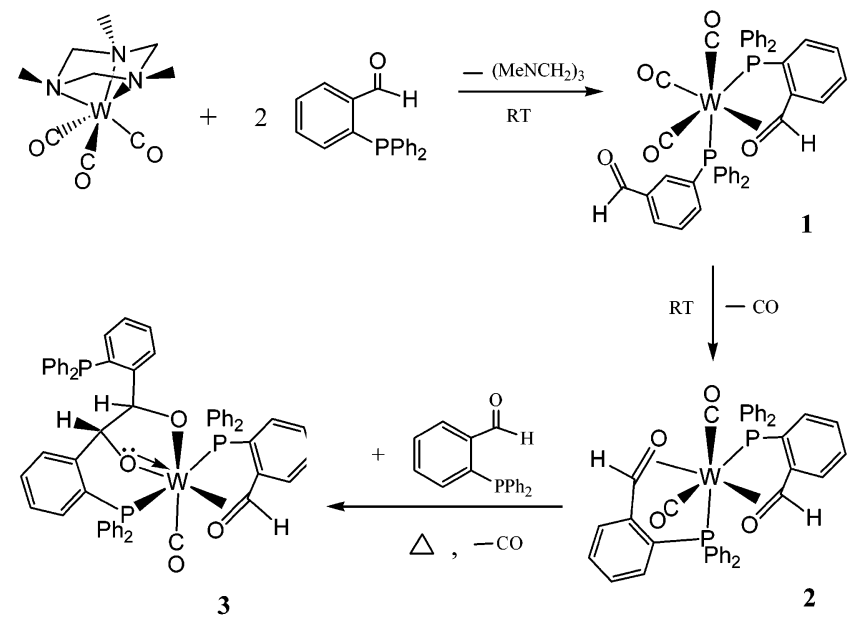

the reaction, the solution color changed from brown to purple, and IR analysis showed complete substitution of the coordinated triazacyclohexane ligand after 30 min, at which point the reaction mixture was worked up. Although compound $\mathbf{l}$ is stable as a solid, in solution it undergoes a facile decarbonylation reaction to generate $\mathrm{W}(\mathrm{CO})_{2}\left(\eta^{3}-\mathrm{PCHO}\right)_{2}$ (2). Alternatively, compound $\mathbf{2}$ can be synthesized directly from the reaction of $\mathrm{W}(\mathrm{CO})_{3^{-}}$ $\left(\eta^{3}-\left(\mathrm{MeNCH}_{2}\right)_{3}\right)$ and $\mathrm{PCHO}$ in dichloromethane at room temperature over a period of $48 \mathrm{~h}$. There is no further reaction between 2 and $\mathrm{PCHO}$ at room temperature, but this mixture leads to the dioxyl complex $\mathrm{W}(\mathrm{CO})\left(\eta^{3}-\right.$ $\mathrm{PCHO})\left(\eta^{3}-(\mathrm{PCHO})_{2}\right)(3 ; 44 \%$ yiel d) in refluxing benzene for $21 \mathrm{~h}$. The results are summarized in Scheme 1.

Compound $\mathbf{1}$ forms a purple crystalline solid. The I R spectrum in the $\mathrm{CO}$ region presents three absorption peaks with the pattern consistent with a fac-W(CO) $)_{3}$ configuration. ${ }^{14}$ The ${ }^{31} \mathrm{P}\left\{{ }^{1} \mathrm{H}\right\}$ NMR displays two doublets at $\delta 12.16$ and $21.50(\mathrm{p}-\mathrm{p}=20 \mathrm{~Hz})$, with both accompanied by ${ }^{183} \mathrm{~W}$ satellites $(\mathrm{P}-\mathrm{W}=108 \mathrm{~Hz}$ ), for the coordinated phosphorus atoms. The ${ }^{1} \mathrm{H}$ NMR spectrum shows an aldehyde proton resonance at $\delta 9.79$, which compares with $\delta 10.50$ for the free PCHO ligand, and an aldehyde proton resonance shifted upfield to $\delta 6.28$, indicating coordination of one al dehyde group. The ${ }^{13} \mathrm{C}$ $\left\{{ }^{1} \mathrm{H}\right\}$ NMR spectrum shows the coordinated and the pendant aldehyde carbon resonances at $\delta 99.4$ and 190.6, respectively.

The molecular structure of $\mathbf{1}$, shown in Figure $\mathbf{1}$, appears as a distorted octahedron. Three carbonyl ligands are terminally bonded to the $\mathrm{W}$ atom in a facial configuration, with the $\mathrm{C}-\mathrm{W}-\mathrm{C}$ angles in the range $82.5(2)-89.8(2)^{\circ}$. One $\mathrm{PCHO}$ ligand is chelated to the $\mathrm{W}$ atom with the aldehyde group in a $\pi$-donation feature, while the other PCHO ligand is $\eta^{1}$-bonded to the $\mathrm{W}$ atom through the phosphorus atom. The two $\mathrm{W}-\mathrm{P}$ lengths are about equal, being $2.568 \pm 0.006 \AA$. The pendant al dehyde group (C23-O5 bond) is coplanar with the connecting arene ring, while the coordinated aldehyde group (C4-O4 bond) is bent away from the adjacent arene plane with the torsional angle O4-C4C5 $-\mathrm{C} 10=44.41^{\circ}$. The C4-O4 length (1.319(6) $\AA$ ) is ca. $0.1 \AA$ longer than that in the pendant aldehyde group

(14) (a) Lukehart, C. M. Fundamental Transition Metal Organometallic Chemistry; Wadsworth: Belmont, CA, 1985. (b) Hsu, S. C. N.; Yeh, W.-Y. J . Chem. Soc., Dalton Trans. 1998, 125.

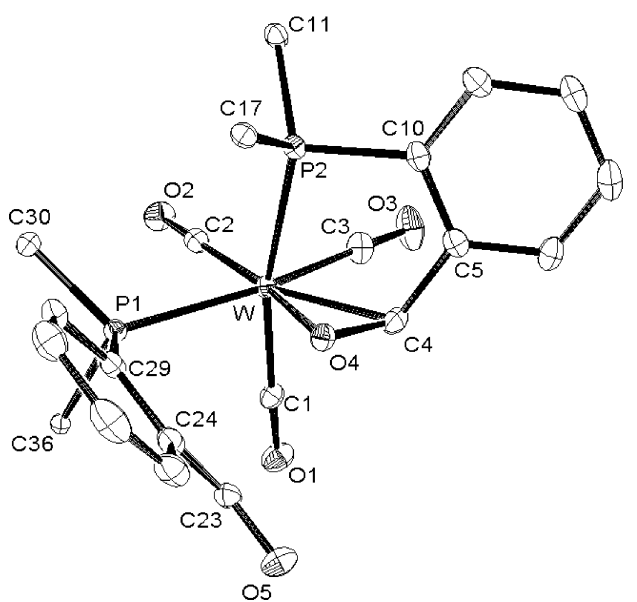

Figure 1. Molecular structure of $\mathbf{1}$. The $\mathrm{C}_{6} \mathrm{H}_{5}$ groups have been artificially omitted, except the ipso carbon atoms, for darity. Selected bond distances $(\AA)$ : $W-P 1=2.563(1)$, $\mathrm{W}-\mathrm{P} 2=2.573(1), \mathrm{W}-\mathrm{C} 1=1.966(5), \mathrm{W}-\mathrm{C} 2=2.002(5)$, $\mathrm{W}-\mathrm{C} 3=1.993(5), \mathrm{W}-\mathrm{C} 4=2.289(5), \mathrm{W}-\mathrm{O} 4=2.155(3)$, $\mathrm{C} 4-\mathrm{O} 4=1.319(6), \mathrm{C} 23-\mathrm{O} 5=1.217(6)$. Selected bond angles (deg): $\mathrm{P} 1-\mathrm{W}-\mathrm{C} 3=166.8(2), \mathrm{P} 2-\mathrm{W}-\mathrm{C} 1=$ 165.8(1), C2-W-C4 = 157.3(2), C2-W-O4 = 167.6(2), $\mathrm{C} 10-\mathrm{P} 2-\mathrm{W}=101.1(2), \mathrm{C} 29-\mathrm{P} 1-\mathrm{W}=114.5(2), \mathrm{C} 5-\mathrm{C} 4-$ $\mathrm{O} 4=119.2(4), \mathrm{C} 24-\mathrm{C} 23-\mathrm{O} 5=123.7(5)$.

(C23-05 $=1.217(6) \AA)$, suggesting a significant $\pi$-backdonation from the tungsten to the $\pi^{*}$ orbital of the $\mathrm{C}=\mathrm{O}$ double bond.

Compound $\mathbf{2}$ forms air-stable, bright yellow crystals. The IR spectrum displays two CO absorptions at 1974 and $1910 \mathrm{~cm}^{-1}$. The $F A B$ mass spectrum gives the molecular ion at $\mathrm{m} / \mathrm{z} 820$, corresponding to a $\mathrm{W}(\mathrm{CO})_{2}$ segment plus two PCHO ligands. However, the ${ }^{31} \mathrm{P}\left\{{ }^{1} \mathrm{H}\right\}$ NMR shows only one resonance at $\delta 10.03$ accompanied by ${ }^{183} \mathrm{~W}$ satellites $(\mathrm{J}-\mathrm{W}=112 \mathrm{~Hz})$, the ${ }^{1} \mathrm{H}$ NMR shows a singlet at $\delta 5.12$ for the coordinated al dehyde protons, and the ${ }^{13} \mathrm{C}\left\{{ }^{1} \mathrm{H}\right\}$ NMR shows the aldehyde carbon resonance at $\delta 81.4$. These NMR data suggest the same coordination mode for the two PCHO ligands.

The molecular structure of $\mathbf{2}$ is illustrated in Figure 2. There are two terminal carbonyl ligands in cis positions with a $\mathrm{C} 1-\mathrm{W}-\mathrm{C} 2$ angle of $86.7(2)^{\circ}$. The two $\mathrm{PCHO}$ ligands are coordinated to the $\mathrm{W}$ atom in an $\eta^{3}$ fashion. The two phosphorus atoms are cis to each other with $\mathrm{W}-\mathrm{P} 1$ and $\mathrm{W}-\mathrm{P} 2$ lengths of 2.586(1) and 2.559(1) $\AA$, respectively, and a P1-W-P2 angle of $100.1(1)^{\circ}$. The two aldehyde groups are in trans positions and are $\eta^{2-}$ bonded to the $\mathrm{W}$ atom with the distances $\mathrm{C} 3-\mathrm{W}=$ 2.218(4) $\AA, \mathrm{O} 3-\mathrm{W}=2.065(3) \AA, \mathrm{C} 22-\mathrm{W}=2.206(4) \AA$, and $\mathrm{O} 4-\mathrm{W}=2.066(3) \AA$. The $\mathrm{C} 3-\mathrm{O} 3$ and $\mathrm{C} 22-\mathrm{O} 4$ vectors, which are bent away from the adjacent arene planes by $54.0^{\circ}$ (average), are about perpendicular to each other, presumably to obtain better $\pi$-back-donation from separate filled $d$ orbitals of the tungsten metal.

The $F A B$ mass spectrum of $\mathbf{3}$ gives the molecular ion at $m / z 1083$, which is equal to combination of a W(CO) moiety and three PCHO molecules. The IR spectrum shows only one CO stretching absorption at $1897 \mathrm{~cm}^{-1}$. In contrast to $\mathbf{1}$ and $\mathbf{2}$, the ${ }^{31} \mathrm{P}\left\{{ }^{1} \mathrm{H}\right\}$ NMR spectrum of $\mathbf{3}$ is more complicated, displaying two doublets at $\delta 22.42$ and $14.56(\mathrm{P}-\mathrm{p}=286 \mathrm{~Hz})$, with both being accompanied by ${ }^{183} \mathrm{~W}$ satellites $(\mathrm{p}-\mathrm{W}=169$ and $149 \mathrm{~Hz}$ ), and a singlet at $\delta-20.02$ for a pendant phosphine group. The large ${ }^{31} \mathrm{P}-{ }^{31} \mathrm{P}$ coupling constant suggests a trans arrangement 


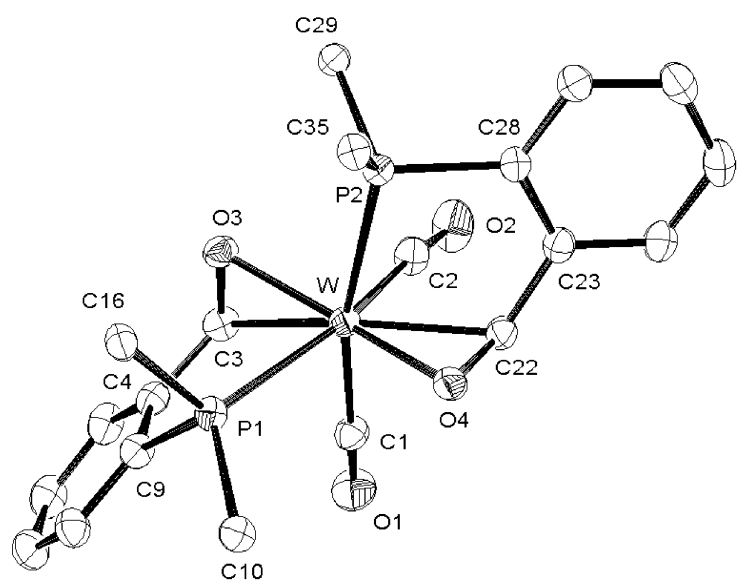

Figure 2. Molecular structure of 2. The $\mathrm{C}_{6} \mathrm{H}_{5}$ groups have been artificially omitted, except the ipso carbon atoms, for clarity. Selected bond distances $(\AA): \mathrm{W}-\mathrm{P} 1=2.586(1)$, $\mathrm{W}-\mathrm{P} 2=2.559(1), \mathrm{W}-\mathrm{C} 1=1.994(5), \mathrm{W}-\mathrm{C} 2=1.994(5)$, $\mathrm{W}-\mathrm{C} 3=2.218(4), \mathrm{W}-\mathrm{O} 3=2.065(3), \mathrm{W}-\mathrm{C} 22=2.206(4)$, $\mathrm{W}-\mathrm{O} 4=2.066(3), \mathrm{C} 3-\mathrm{O} 3=1.338(5), \mathrm{C} 22-\mathrm{O} 4=$ 1.357(5). Selected bond angles (deg): $\mathrm{P} 1-\mathrm{W}-\mathrm{C} 2=$ 165.0(1), P2-W-C1 = 166.7(1), C3-W-C22 = 152.7(2), $\mathrm{C} 3-\mathrm{W}-\mathrm{O} 4=155.2(1), \mathrm{O} 3-\mathrm{W}-\mathrm{O} 4=155.0(1), \mathrm{O} 3-\mathrm{W}-\mathrm{C} 22$ $=154.7(1), C 9-\mathrm{P} 1-\mathrm{W}=99.6(2), \mathrm{C} 28-\mathrm{P} 2-\mathrm{W}=101.8(1)$, $\mathrm{C} 23-\mathrm{C} 22-\mathrm{O} 4=117.3(4), \mathrm{C} 4-\mathrm{C} 3-\mathrm{O} 3=120.1(4)$.

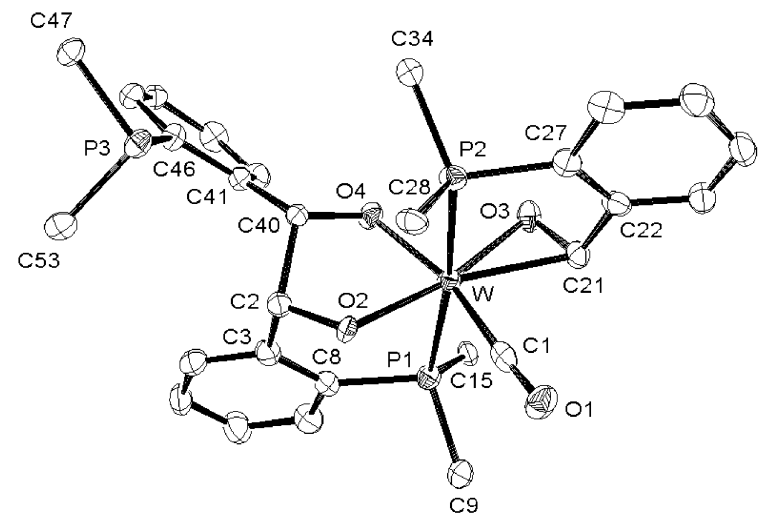

Figure 3. Molecular structure of 3. The $\mathrm{C}_{6} \mathrm{H}_{5}$ groups have been artificially omitted, except the ipso carbon atoms, for clarity. Selected bond distances $(\AA): \mathrm{W}-\mathrm{P} 1=2.522(3)$, $\mathrm{W}-\mathrm{P} 2=2.503(3), \mathrm{W}-\mathrm{C} 1=1.95(1), \mathrm{W}-\mathrm{C} 21=2.18(1)$ $\mathrm{W}-\mathrm{O} 3=1.948(7), \mathrm{W}-\mathrm{O} 2=1.945(6), \mathrm{W}-\mathrm{O} 4=2.091(7)$, $\mathrm{C} 1-\mathrm{O} 1=1.17(1), \mathrm{C} 21-\mathrm{O} 3=1.36(1), \mathrm{C} 2-\mathrm{O} 2=1.42(1)$, $\mathrm{C} 40-\mathrm{O} 4=1.39(1), \mathrm{C} 2-\mathrm{C} 40=1.57(1)$. Selected bond angles (deg): $\mathrm{P} 1-\mathrm{W}-\mathrm{P} 2=173.02(9), \mathrm{O} 4-\mathrm{W}-\mathrm{C} 1=166.7(3), \mathrm{O} 2-$ $\mathrm{W}-\mathrm{C} 21=157.3(3), \mathrm{O} 2-\mathrm{W}-\mathrm{O} 3=164.6(3), \mathrm{C} 22-\mathrm{C} 21-\mathrm{O} 3$ $=116.8(9), \mathrm{C} 3-\mathrm{C} 2-\mathrm{O} 2=113.3(8), \mathrm{C} 3-\mathrm{C} 2-\mathrm{C} 40=$ $112.7(8), \quad \mathrm{O} 2-\mathrm{C} 2-\mathrm{C} 40=103.5(8), \mathrm{C} 2-\mathrm{C} 40-\mathrm{O} 4=$ 105.8(8), $\mathrm{C} 41-\mathrm{C} 40-\mathrm{C} 2=115.5(8), \quad 04-\mathrm{C} 40-\mathrm{C} 2=$ 105.8(8).

for the two coordinated phosphines. Furthermore, in addition to the phenyl proton resonances, the ${ }^{1} \mathrm{H}$ NMR spectrum shows two $1 \mathrm{H}$ multiplets at $\delta 6.44$ and 6.05 and one $1 \mathrm{H}$ singlet at $\delta 6.00$. Because of the absence of diagnostic spectral features to reveal the structure of 3, a single-crystal X-ray diffraction study was performed.

The molecular structure of $\mathbf{3}$ is depicted in Figure 3, in which the tungsten atom is bonded to terminal $\mathrm{CO}$, $\eta^{3}-\mathrm{PCHO}$, and $\eta^{3}-\mathrm{Ph}_{2} \mathrm{P}\left(\mathrm{o}-\mathrm{C}_{6} \mathrm{H}_{4}\right) \mathrm{CH}(\mathrm{O}-) \mathrm{CH}(\mathrm{O}-)\left(\mathrm{o}-\mathrm{C}_{6} \mathrm{H}_{4}\right)-$ $\mathrm{PPh}_{2}$ ligands. The atoms $\mathrm{C} 21, \mathrm{O} 3, \mathrm{~W}, \mathrm{C} 1, \mathrm{O} 1, \mathrm{O} 2$, and $\mathrm{O} 4$ are about coplanar, while the two phosphorus atoms

\section{Chart 2}

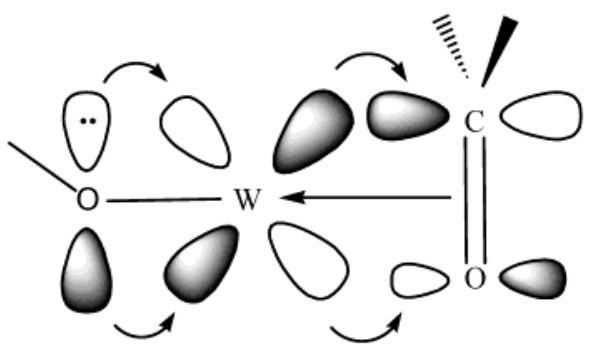

filled $p$-orbital empty $d$-orbital empty $\pi^{*}$-orbital

are on opposite sides with a $\mathrm{P} 1-\mathrm{W}-\mathrm{P} 2$ angle of $173.02(9)^{\circ}$. The aldehyde $\mathrm{C} 21-\mathrm{O} 3$ bond is bent away from the adjacent arene plane by $61.6^{\circ}$. The dioxyl group is apparently derived from coupling of two aldehyde carbons of the PCHO ligands. ${ }^{15}$ The bond angles surrounding the $\mathrm{C} 2$ and $\mathrm{C} 40$ atoms are in the range $103.5(8)-115.5(8)^{\circ}$ (average $\left.110.2^{\circ}\right)$, consistent with an $\mathrm{sp}^{3}$ hybridization. The $\mathrm{C} 40-\mathrm{O} 4$ and $\mathrm{C} 2-\mathrm{O} 2$ bonds are staggered with a torsional angle of $52.94^{\circ}$. Noticeably, the $\mathrm{W}-\mathrm{O} 2$ bond length (1.945(6) $\AA$ ) is $0.15 \AA$ shorter than the W-O4 bond length (2.091(7) $\AA$ ), and the $\eta^{2}$-aldehyde group is coordinated to the tungsten atom much more strongly than those in $\mathbf{1}$ and $\mathbf{2}$, with $\mathrm{W}-\mathrm{C} 21$ $=2.18(1) \AA$ and $\mathrm{W}-\mathrm{O} 3=1.948(7) \AA$.

Since the carbonyl, phosphine, and $\eta^{2}$-al dehyde ligands are normally considered as two-electron donors, the remaining dioxyl ligand must provide six electrons to the W(II) atom to satisfy the 18-electron rule. Thus, the shorter $\mathrm{W}-\mathrm{O} 2$ length in comparison with the $\mathrm{W}-\mathrm{O} 4$ length can be explained by $\pi$ donation of a lone pair from the $\mathrm{O} 2$ atom to the tungsten, giving the $\mathrm{W}-\mathrm{O} 2$ bond a partial double-bond character. This $\pi$ donation can be stabilized by el ectron delocalization over the $\pi^{*}$ orbital of the $\eta^{2}$-al dehyde group (Chart 2).

The aldehyde-transition-metal complexes are well documented, where aldehydes coordinate in a $\sigma$ or $\pi$ fashion depending on the metals, the oxidation states, and the steric requirements of the substrate and the ancillary ligands. ${ }^{16}$ For instance, $p$-anisaldehyde appears as a $\sigma$ donor in complexation with [TpMo(CO)$\left.\left(\mathrm{C}_{2} \mathrm{Me}_{2}\right)\right]^{+}$but as a $\pi$ donor with $\left[\mathrm{TpW}(\mathrm{CO})\left(\mathrm{C}_{2} \mathrm{Me}_{2}\right)\right]^{+}(\mathrm{Tp}$ $=$ hydridotripyrazolylborate), ${ }^{17}$ whereas the phthalaldehyde complex of [Cp*Co] contains both $\sigma$ - and $\pi$-bonded aldehyde groups. ${ }^{11}$ It has been argued that the higher electron density at the metal center favors binding of the aldehyde in a $\pi$ fashion with significant backbonding from metal to the $\pi^{*}$ orbital of the carbonyl group. ${ }^{11} \mathrm{~F}$ or compounds $\mathbf{1}-\mathbf{3}$, the phosphineligands are good electron donors and the tungsten centers are in low oxidation states; thus, it is easy to rationalize that the aldehyde groups prefer to bind through $\pi$ interactions.

\section{Experimental Section}

General Methods. All manipulations were carried out under an atmosphere of dinitrogen with standard Schlenk

(15) Refosco, F.; Bandoli, G.; Mazzi, U.; Tisato, F.; Dolmella, A.; Nicolini, M. Inorg. Chem. 1990, 29, 2179.

(16) Collman, J . P.; Hegedus, L. S.; Norton, J . R.; Finke, R. G. Principles and Applications of Organotransition Metal Chemistry; University Science Books: Mill Valley, CA, 1987.

(17) Schuster, D. M.; White, P. S.; Templeton, J . L. Organometallics 1996, 15, 5467. 
techniques. $\mathrm{W}(\mathrm{CO})_{3}\left(\eta^{3}-\left(\mathrm{MeNCH}_{2}\right)_{3}\right)$ was prepared by literature methods. ${ }^{12} \mathrm{Ph}_{2} \mathrm{P}\left(\mathrm{o}-\mathrm{C}_{6} \mathrm{H}_{4}\right) \mathrm{C}(=\mathrm{O}) \mathrm{H}$ (abbreviated as $\mathrm{PCHO}$ ) was purchased from Aldrich and used as received. Solvents were dried over appropriate reagents under dinitrogen and distilled immediately before use. ${ }^{1} \mathrm{H},{ }^{31} \mathrm{P}$, and ${ }^{13} \mathrm{C}$ NMR spectra were obtained on a Varian Unity INOVA-500 spectrometer. Fastatom-bombardment ( $F A B)$ mass spectra were recorded on a J EOL J MS-SX102A mass spectrometer. Elemental analyses were performed at the National Science Council Regional Instrumentation Center at National Chen-Kung University, Tainan, Taiwan.

Preparation of 1. $\mathrm{W}(\mathrm{CO})_{3}\left(\eta^{3}-\left(\mathrm{MeNCH}_{2}\right)_{3}\right)$ (42 mg, 0.1 $\mathrm{mmol})$ and dichloromethane $(10 \mathrm{~mL})$ were placed in an ovendried $50 \mathrm{~mL}$ Schlenk flask, equipped with a magnetic stir bar and a rubber serum stopper. PCHO (93 $\mathrm{mg}, 0.32 \mathrm{mmol}$ ) in dichloromethane solvent $(5 \mathrm{~mL})$ was then introduced into the flask, and the mixture was stirred at room temperature for $30 \mathrm{~min}$, yielding a purple solution. The solution was filtrated under dinitrogen, and the volatile materials were removed under vacuum. The residue was crystallized from dichloromethane/n-hexane to afford an air-stable, purple crystalline solid of $\mathrm{W}(\mathrm{CO})_{3}\left(\eta^{1}-\mathrm{PCHO}\right)\left(\eta^{3}-\mathrm{PCHO}\right)(\mathbf{1} ; 46 \mathrm{mg}, 0.054 \mathrm{mmol}$, 54\%). Anal. Calcd for $\mathrm{C}_{41} \mathrm{H}_{30} \mathrm{O}_{5} \mathrm{P}_{2} \mathrm{~W}$ : C, 58.05; $\mathrm{H}, 3.56$. F ound: C, 58.40; H, 3.85. IR ( $\left.\mathrm{CH}_{2} \mathrm{Cl}_{2}, v_{\mathrm{CO}}\right): 1972$ (s), 1904 (s), 1864 (s) $\mathrm{cm}^{-1}$. MS (FAB): $\mathrm{m} / \mathrm{z} 848\left(\mathrm{M}^{+},{ }^{184} \mathrm{~W}\right), 848-28 \mathrm{n}(\mathrm{n}=1-3)$. ${ }^{1} \mathrm{H} \mathrm{NMR}\left(\mathrm{CD}_{2} \mathrm{Cl}_{2}, 22^{\circ} \mathrm{C}\right): \delta 9.79(\mathrm{~s}, 1 \mathrm{H}$, free $\mathrm{CHO}), 7.59-6.20$ (m, 28H, Ph), $6.28\left(\mathrm{~s}, 1 \mathrm{H}, \eta^{2}-\mathrm{CHO}\right) .{ }^{31} \mathrm{P}\left\{{ }^{1} \mathrm{H}\right\} \mathrm{NMR}\left(\mathrm{CD}_{2} \mathrm{Cl}_{2}, 22\right.$ $\left.{ }^{\circ} \mathrm{C}\right): \delta 12.16\left(\mathrm{~d}, \mathrm{~J}_{\mathrm{p}-\mathrm{p}}=20 \mathrm{~Hz}\right.$; with ${ }^{183} \mathrm{~W}$ satellites $\mathrm{J} \mathrm{p}-\mathrm{W}=108$ $\mathrm{Hz}), 21.50\left(\mathrm{~d}, \mathrm{~J}_{\mathrm{P}-\mathrm{p}}=20 \mathrm{~Hz}\right.$; with ${ }^{183} \mathrm{~W}$ satellites J $\mathrm{p}-\mathrm{W}=108$ $\mathrm{Hz}) \cdot{ }^{13} \mathrm{C}\left\{{ }^{1} \mathrm{H}\right\}$ NMR $\left(\mathrm{CD}_{2} \mathrm{Cl}_{2}, 22{ }^{\circ} \mathrm{C}\right): \delta 227.5(\mathrm{~m}, \mathrm{CO}), 211.6$ $\left(\mathrm{dd}, \mathrm{CO}, \mathrm{J}_{\mathrm{p}-\mathrm{c}}=6,16 \mathrm{~Hz}\right), 207.6(\mathrm{dd}, \mathrm{CO}$, J $\mathrm{p}-\mathrm{c}=5,50 \mathrm{~Hz})$, 190.6 (d, free $\mathrm{CHO}, \mathrm{J}_{\mathrm{p}-\mathrm{C}}=8 \mathrm{~Hz}$ ), 153.4-127.9 (Ph), 99.4 $\left(\eta^{2}-\mathrm{CHO}\right)$.

Preparation of 2. A solution of $\mathrm{PCHO}(90 \mathrm{mg}, 0.31 \mathrm{mmol})$ in dichloromethane $(5 \mathrm{~mL})$ was added into a flask containing $\mathrm{W}(\mathrm{CO})_{3}\left(\eta^{3}-\left(\mathrm{MeNCH}_{2}\right)_{3}\right)(40 \mathrm{mg}, 0.10 \mathrm{mmol})$ and dichloromethane $(10 \mathrm{~mL})$. The mixture was stirred at room temperature for 48 $\mathrm{h}$, showing the solution color change from brown to purple to orange. The solution was filtered under dinitrogen, and the volatile materials were removed under vacuum. The residue was crystall ized from dichloromethane/n-hexane to afford airstable, bright yellow crystals of $\mathrm{W}(\mathrm{CO})_{2}\left(\eta^{3}-\mathrm{PCHO}\right)_{2}(2 ; 38 \mathrm{mg}$, $0.046 \mathrm{mmol}, 46 \%)$. Anal. Calcd for $\mathrm{C}_{40} \mathrm{H}_{30} \mathrm{O}_{4} \mathrm{P} 2 \mathrm{~W}: \mathrm{C}, 58.56 ; \mathrm{H}$, 3.69. Found: $\mathrm{C}, 58.17 ; \mathrm{H}, 3.79$. IR $\left(\mathrm{CH}_{2} \mathrm{Cl}_{2}, v_{\mathrm{CO}}\right): 1974$ (s), 1910 (s) $\mathrm{cm}^{-1}$. MS (FAB): $\mathrm{m} / \mathrm{z} 820\left(\mathrm{M}^{+},{ }^{184} \mathrm{~W}\right), 820-28 \mathrm{n}(\mathrm{n}=1-2)$. ${ }^{1} \mathrm{H}$ NMR $\left(\mathrm{CD}_{2} \mathrm{Cl}_{2}, 22{ }^{\circ} \mathrm{C}\right): \delta 7.64-6.93(\mathrm{~m}, 28 \mathrm{H}, \mathrm{Ph}), 5.12(\mathrm{~s}$, $2 \mathrm{H}, \eta^{2}$-CHO). ${ }^{31} \mathrm{P}\left\{{ }^{1} \mathrm{H}\right\} \mathrm{NMR}\left(\mathrm{CD}_{2} \mathrm{Cl}_{2}, 22{ }^{\circ} \mathrm{C}\right): \delta 10.03$ (s; with ${ }^{183} \mathrm{~W}$ satellites J P-W $\left.=112 \mathrm{~Hz}\right) .{ }^{13} \mathrm{C}\left\{{ }^{1} \mathrm{H}\right\} \mathrm{NMR}\left(\mathrm{CD}_{2} \mathrm{Cl}_{2}, 22{ }^{\circ} \mathrm{C}\right)$ : $\delta 207.1$ (dd, CO, J $\mathrm{P}-\mathrm{C}=13,58 \mathrm{~Hz}$ ), 156.3-127.8 (Ph), 81.4 $\left(\eta^{2}-\mathrm{CHO}\right)$.

Transformation of $\mathbf{1}$ to 2 . A solution of $\mathbf{1}(20 \mathrm{mg})$ in dichloromethane $(10 \mathrm{~mL}$ ) was stirred at room temperature under dinitrogen. The reaction was monitored by IR to show complete conversion of $\mathbf{1}$ to $\mathbf{2}$ over a period of $\mathbf{4 8} \mathrm{h}$.

Preparation of 3. Compound 2 (22 mg, $0.027 \mathrm{mmol})$, PCHO (17 mg, $0.058 \mathrm{mmol})$, and benzene $(10 \mathrm{~mL})$ were added into a flask equipped with a reflux condenser. The solution was heated to reflux for $21 \mathrm{~h}$ under dinitrogen. The solution was cooled to room temperature, and the sol vent was removed under vacuum. The residue was crystallized from dichloromethane/n-hexane/diethyl ether to afford air-stable, brownish
Table 1. Crystallographic Data for 1-3

\begin{tabular}{|c|c|c|c|}
\hline & 1 & 2 & 3 \\
\hline $\begin{array}{l}\text { chem formula } \\
\text { cryst solvent }\end{array}$ & $\mathrm{C}_{41} \mathrm{H}_{30} \mathrm{O}_{5} \mathrm{P}_{2} \mathrm{~W}$ & $\mathrm{C}_{40} \mathrm{H}_{30} \mathrm{O}_{4} \mathrm{P}_{2} \mathrm{~W}$ & $\begin{array}{l}\mathrm{C}_{58} \mathrm{H}_{45} \mathrm{O}_{4} \mathrm{P}_{3} \mathrm{~W} \\
\mathrm{CH}_{2} \mathrm{Cl}_{2}+0.5 \mathrm{Et}_{2} \mathrm{O}\end{array}$ \\
\hline cryst syst & monoclinic & monoclinic & triclinic \\
\hline fw & 848.44 & 82 & 1200 \\
\hline $\mathrm{T}, \mathrm{K}$ & 150 & 295 & 150 \\
\hline space group & $\mathrm{P} 2 \mathrm{z} / \mathrm{n}$ & $\mathrm{P} 2 \mathrm{l} / \mathrm{n}$ & $\mathrm{P} \overline{1}$ \\
\hline$a, \AA$ & $10.8844(1)$ & $9.4288(4)$ & $9.8218(9)$ \\
\hline b, A & $17.7818(2)$ & $16.9288(7)$ & 13.7 \\
\hline$c, \AA$ & $17.5881(2)$ & $21.2946(9)$ & $01(2)$ \\
\hline$\alpha$, deg & 90 & 90 & $73.649(2)$ \\
\hline$\beta$, deg & $91.9127(3)$ & 101.595(1) & $83.467(2)$ \\
\hline$\gamma$, deg & 90 & 90 & $73.488(2)$ \\
\hline $\mathrm{V}, \AA^{3}$ & 18(6) & $3329.6(2)$ & $2633.0(4)$ \\
\hline Z & 4 & 4 & 2 \\
\hline$\overline{\mathrm{D}}_{\mathrm{calcd}}, \mathrm{g} \mathrm{cm}^{-3}$ & 1.656 & 1.637 & 1.514 \\
\hline$\mu, \mathrm{mm}^{-1}$ & 3.536 & 3.607 & 2.436 \\
\hline $\mathrm{R} 1 / \mathrm{wR} 2^{\mathrm{a}}$ & $0.0356 / 0.0755$ & $0.0365 / 0.0809$ & $0.0690 / 0.1538$ \\
\hline GOF on $\mathrm{F}^{2}$ & 1.106 & 1.090 & 1.041 \\
\hline
\end{tabular}

yellow crystals of $\mathrm{W}(\mathrm{CO})\left(\eta^{3}-\mathrm{PCHO}\right)\left(\eta^{3}-(\mathrm{PCHO})_{2}\right)(3 ; 13 \mathrm{mg}$, $0.012 \mathrm{mmol}, 44 \%)$. IR $\left(\mathrm{CH}_{2} \mathrm{Cl}_{2}, v_{\mathrm{CO}}\right): 1897$ (s) $\mathrm{cm}^{-1}$. MS (FAB): $\mathrm{m} / \mathrm{z} 1082\left(\mathrm{M}^{+},{ }^{184} \mathrm{~W}\right), 1056\left(\mathrm{M}^{+}-\mathrm{CO}\right) .{ }^{1} \mathrm{H} \mathrm{NMR}\left(\mathrm{CD}_{2^{-}}\right.$ $\left.\mathrm{Cl}_{2}, 22{ }^{\circ} \mathrm{C}\right): \delta 7.57-6.48(\mathrm{~m}, 42 \mathrm{H}, \mathrm{Ph}), 6.44(\mathrm{~m}, 1 \mathrm{H}, \mathrm{CH}-\mathrm{O})$, $6.05(\mathrm{~m}, 1 \mathrm{H}, \mathrm{CH}-\mathrm{O}), 6.00\left(\mathrm{~s}, 1 \mathrm{H}, \eta^{2}-\mathrm{CHO}\right) .{ }^{31} \mathrm{P}\left\{{ }^{1} \mathrm{H}\right\} \mathrm{NMR}\left(\mathrm{CD}_{2^{-}}\right.$ $\left.\mathrm{Cl}_{2}, 22{ }^{\circ} \mathrm{C}\right): \delta 22.42\left(\mathrm{~d}, \mathrm{~J}_{\mathrm{P}-\mathrm{P}}=286 \mathrm{~Hz}\right.$; with ${ }^{183 \mathrm{~W}}$ satellites $\left.\mathrm{J}_{\mathrm{P}-\mathrm{W}}=169 \mathrm{~Hz}\right), 14.56\left(\mathrm{~d}, \mathrm{~J}_{\mathrm{P}-\mathrm{P}}=286 \mathrm{~Hz}\right.$; with ${ }^{183 \mathrm{~W}}$ satellites $\mathrm{J} p-w=149 \mathrm{~Hz}),-20.02(\mathrm{~s}) \cdot{ }^{13} \mathrm{C}\left\{{ }^{1} \mathrm{H}\right\} \mathrm{NMR}\left(\mathrm{CD}_{2} \mathrm{Cl}_{2}, 22{ }^{\circ} \mathrm{C}\right): \delta$ 223.0 (CO), 157.2-126.0 (Ph), $98.1\left(\eta^{2}-\mathrm{CHO}\right), 85.6$ (d, J p-C $=$ $30 \mathrm{~Hz}, \mathrm{CH}-\mathrm{O}), 84.8(\mathrm{~d}, \mathrm{~J}-\mathrm{C}=5 \mathrm{~Hz}, \mathrm{CH}-\mathrm{O})$.

Structure Determinations for $\mathbf{1}-\mathbf{3}$. The crystals of 1-3 found suitable for X-ray analysis were each mounted in a thinwalled glass capillary and aligned on Nonius KappaCCD (for 2) and Bruker Smart ApexCCD (for 1 and 3) diffractometers, with graphite-monochromated Mo K $\alpha$ radiation $(\lambda=0.71073$ $\AA$ ). The $\theta$ range for data collection is $1.63-27.50^{\circ}$ for $1,1.55-$ $27.50^{\circ}$ for $\mathbf{2}$, and $1.00-25.00^{\circ}$ for 3 . Of the 24819,33047 , and 24760 reflections collected for $\mathbf{1}-\mathbf{3}, 7816,7644$, and 9291 reflections were independent, respectively. All data were corrected for L orentz and polarization effects and for the effects of absorption. The structure was solved by direct methods and refined by least-squares cycles. The non-hydrogen atoms were refined anisotropically. Hydrogen atoms were included but not refined. All calculations were performed using the SHELXTL97 package. ${ }^{18}$ The data collection and refinement parameters are presented in Table 1.

Acknowledgment. We are grateful for support of this work by the National Science Council of Taiwan.

Supporting Information Available: Complete tables of crystallographic data, positional parameters, anisotropic thermal parameters, bond angles, and bond distances of 1-3; crystallographic data are also available as CIF files. This material is available free of charge via the Internet at http://pubs.acs.org.

\section{OM0343061}

(18) Sheldrick, G. M. SHELXTL-97, Program for Crystal Structure Refinement; University of Göttingen, Göttingen, Germany, 1997. 